\author{
Daniel Naurin \\ PluriCourts, University of Oslo, and the \\ Department of Political Science, University of Gothenburg \\ Daniel.naurin@jus.uio.no
}

May 14, 2018

\title{
Liberal intergovernmentalism in the Councils of the EU: a baseline theory?
}

[Running Head: LI in the Councils: a baseline theory?]

\begin{abstract}
How has the research on the European Council and the Council of the EU engaged with Moravcsik's theory on liberal intergovernmentalism (LI)? This article analyses 25 years of Council research. Most of this literature does not refer to LI, and a majority of the references that are made raise critique against LI. However, compared to other major works on European integration, LI is by far the most important source in the Council literature. Furthermore, a closer look at the most significant challenges raised against LI indicates that its account of intergovernmental bargaining in the EU is not in serious question. On the other hand, few studies provide systematic tests of the key assumptions of LI with regards to interstate bargaining. As a result, the self-proclaimed status of LI as a baseline theory is confirmed in the Council literature more by implicit, somewhat reluctant, consent than by overt support.
\end{abstract}




\section{Introduction}

Liberal intergovernmentalism (LI) understands European integration as the product of agreements negotiated by states on the basis of preferences derived from domestic political equilibria (Moravcsik 1993, 1998). Interstate bargaining is at the core of the theory. The two main arenas where such bargaining takes place in the EU system are the European Council and the Council of Ministers. The former brings together heads of state and governments and has the role of providing general leadership and coordination in the EU. The Council, where line ministers meet, has both legislative and executive tasks in the everyday policy-making of the EU (Hayes-Renshaw and Wallace 2006). Although the Council in its legislative functions is formally placed in a bicameral setting with the European Parliament (EP), and with agendasetting powers delegated to the European Commission, the Council is arguably the most powerful institution in the EU system (Thomson 2011:210).

A substantial body of literature has studied negotiations in the two Councils in the 25 years since the publication of Preferences and Power in 1993. The main purpose of this article is to assess the impact of LI on this research, and analyze how the leading scholarship has engaged with LI. To what extent have scholars studying the negotiations in the Councils verified, refuted or complemented key elements of LI? What are the most important challenges raised with respect to LI's account of interstate bargaining?

A possible objection to this approach is to argue that LI was initially developed as a theory of decentralized "grand bargains" in the history of European integration, and that looking for impact on the research on the highly institutionalized everyday policy-making in the Council of Ministers may not make much sense. Moravcsik, on the other hand, has argued that "LI theory applies far beyond treaty-amending decisions, well into the realm of everyday EU decision-making" (Moravcsik and Schimmelfennig 2009:74). LI is based on general theoretical concepts (e.g. rational state actors, issue-specific preference functions, the Nash bargaining solution, asymmetric interdependence) that may be more or less relevant in different contexts. I will discuss approaches that are critical and those that are favorable of an application of LI also to Council negotiations.

The article contains three sections. In the first part, I run a series of searches in the Social Science Citation Index to derive a body of literature to analyze further. I then conduct a systematic content analysis of the most important articles in that literature, as measured by the 
number of citations. I find, on the one hand, that most of the Council research does not refer to LI, and that most of the references to LI are made in studies not focusing primarily on the Councils. On the other hand, in relative terms, LI is by far the most frequently used theoretical source in the research on the Councils of the EU.

That is not to say that the Council literature generally endorses the claims made in LI. To the contrary, an analysis of the 70 most cited articles in the identified body of Council research demonstrates that an overwhelming majority of the references made raise critique against one or several propositions made in the theory. The most frequent type of criticism relates to the assumptions made with regards to the formation and articulation of member states' preferences, and in particular the assumption that preferences are exogenous to the bargaining process. This critique is often connected to broader epistemological and methodological debates in EU studies. Scholars that raise critique towards the interstate bargaining phase tend to focus either on the modes of interaction (arguing/bargaining), or on the inherent (in)effectiveness of the negotiations, rather than on the distributive side. LI's account of how gains are distributed, as determined by the relative values the parties attach to cooperation, remains largely unchallenged.

The content analysis also reveals that although the critical points raised against LI outnumbers the ones in support, few studies seriously set out to challenge key components of LI. An important feature of liberal intergovernmentalism, that is explicitly emphasized by Moravcsik, is that its assumptions and predictions are transparent, parsimonious and empirically testable (Moravcsik 1998:10). Still, there are few examples among the studies analyzed here that explicitly aim to test hypotheses derived from LI. Most of the references instead serve one of three functions; of using a selected claim made in LI as support for an argument or assumption made by the author; of elevating the overall significance of the author's argument by connecting it to broader theoretical accounts of European integration (often in the introduction or conclusion of the article); or of criticizing LI for only providing an incomplete account of a particular phenomenon that the author is interested in. Thus, more than verifying or refuting LI, the way the theory is applied in the Council research contributes to an ongoing, mainly implicit, confirmation of its self-proclaimed status as a baseline theory of European integration (Moravcsik and Schimmelfennig 2009:67).

The third part of the article addresses one of the most important challenges raised against LI in the Council literature. It relates to the post-functionalist argument that the sector-specific 
political-economic rationality central to LI is being superseded by identity and ideology as the main sources of member states' preferences. In this section, I go beyond the set of studies in the content analysis to examine the available empirical evidence behind this challenge. I conclude that the basic building blocks of LI, including the importance of asymmetric interdependence based on sectoral issue-specific preferences, hardly are less relevant in the new era of 'constraining dissensus' than it was during the time of 'permissive consensus'.

\section{What impact has LI had on the Council research?}

In order to estimate the impact of LI on the research on the Councils of the EU, and to identify a relevant sample of studies to analyze further, I conducted a series of searches in the Thomson Reuters Social Science Citations Index (SSCI). The main advantage of this approach is that the sample is not affected by my subjective views of what constitutes the relevant body of literature. An important but necessary limitation, however, is that only journal articles are included in the sample. This may affect the evaluation of the literature as book-length projects have better opportunities to engage more empirical data, and in particular qualitative and documentary sources. It seems unlikely, however, that the distribution of themes containing support and critique against LI would be much different from the one presented here if books were also included in the sample.

First, a search within all 244 journals listed in Political Science, International Relations and Public Administration generated 687 articles relating to the "European Union" (or "EU") and "Council" during the period 1994-2017. ${ }^{1} 109$ of these (16\%) cite either Preferences and Power or The Choice for Europe (or both) - the two primary works of liberal intergovernmentalist theory. Furthermore, a second set of searches show that articles directly focusing on the Councils of the EU constitute a relatively small share of the total number of studies citing the two main sources of LI. The Choice for Europe had 826 citations in total in the SSCI at the time of the search, while Preferences and Power had 433 citations. ${ }^{2}$ No less

\footnotetext{
${ }^{1}$ The topic search includes title, abstract, author keywords and 'KeyWords Plus' (index terms created by Thomson Reuters from significant, frequently occurring words in the titles of an article's cited references). Search date: 7/4 2017.

2 This includes journals in a broader set of disciplines, including both political science, IR, public administration, economics and law.
} 
than 1139 articles referred to one or both of the two texts. A search on "Council" within this set of studies generated 140 articles (12\%). This is more than similar searches on "Court" (72 articles) and "Parliament" (97 articles), and somewhat less than "Commission" (163 articles).

Two conclusions can be drawn from this simple exercise: Most of the scholarly work that refers to liberal intergovernmentalist theory is not primarily related to research on the Councils of the EU, and most of the research on the Councils does not explicitly refer to LI. Does that mean that the overlap between LI and Council research is lower than one would have expected? Not necessarily. Many of the 1139 articles that cite LI, but were not among the 140 articles captured in the topic-search on the Council, are likely to be relevant for understanding intergovernmental negotiations in the Councils, although their focus is broader than the Councils. ${ }^{3}$ It is of course also conceivable that some of the work on the Councils have been inspired by LI without explicitly acknowledging that by means of a reference. ${ }^{4}$ Furthermore, and most importantly, no other significant work on European integration comes close to these figures. ${ }^{5}$ Thus, while 16 per cent may not at a first glance appear extraordinarily

${ }^{3}$ Some of the most cited articles in this category include Pierson 1996, Pollack 1997, Schimmelfennig 2001, Marks, Hooghe and Blank 1996 and Hix 1999.

${ }^{4}$ Arguably, one of the most significant contributions to the Council research in the time period studied here is the work of Robert Thomson (e.g. Thomson 2011). The key findings of his research regarding the sources of preferences of member states, the relative power of the Council and the supranational institutions, and the bargaining dynamics in the Council, corroborates central parts of LI. However, Thomson rarely explicitly relates his work to LI, which he considers less suited for giving "relevant theoretical guidance for the analysis of how specific controversies are resolved within the EU system" (Thomson 2011:7).

${ }^{5}$ The 109 articles citing Preferences and Power and/or The Choice for Europe may be compared, for example, to Haas' Uniting of Europe (cited by 27 articles in the Council sample), Scharpf's Joint Decision-Trap (cited by 23), Pierson's Path to European Integration (cited by 18). Looking at the most cited rationalist institutionalist and constructivist works shows that 61 out of the 692 articles in the sample of Council research cite either Garrett and Tsebelis 1996 or Tsebelis and Garrett 2001 (or both), while 46 of the articles cite at least one of Checkel's five articles in 1998-2005 relating to constructivism in IR, and 21 articles cite Risse's Let's Argue. Texts relating to multi-level governance and postfunctionalism (Marks, Hooghe and Blank 1996 and/or Hooghe and Marks 2009) are cited by 14 articles in the sample. 
high, in relative terms LI is by far the most frequently used theoretical source in the research on the Councils of the EU. Compared to other theories, LI dominates the research on those EU institutions where intergovernmental bargaining takes place.

\section{Applying liberal intergovernmentalism to the Councils}

Liberal intergovernmentalism is thus relatively frequently cited in the research on the Councils of the EU. How do scholars apply the theory in their work? To what extent has the research on the Councils engaged in testing hypotheses derived from LI? Which aspects of LI have received support in the Council research, and what are the main areas of critique?

To address these questions, I have analyzed a subset of those 140 articles that explicitly address one of the Councils of the EU (or both), and cite The Choice for Europe and/or Preferences and Power. The selection is based on impact, and includes those 70 articles that had received 10 or more citations in the SSCI. ${ }^{6}$ In reviewing these articles, I have looked at to what extent LI is a central theoretical component of the argument made, which themes within LI that are addressed in the article, the main methodological approach taken, and whether the article supports or raises critique against assumptions and claims made within LI. In this section I will give a brief summary of the results. For information about the coding scheme, descriptive statistics and a full list of references I refer to the appendix accompanying this article.

The extent to which the articles in the sample actually engage with liberal intergovernmentalism varies. Fairly often, LI is referred to briefly in the introduction or the conclusion of the article, as the author strives to tie his or her argument to broader debates on European integration. In more than 60 per cent of the articles LI is not central to the arguments made, by providing key hypotheses tested in the article or being a main point of reference in the argument made. In many articles ( 35 per cent), a reference to one of the assumptions or propositions in LI is used mainly as support, to back up the author's own argument, rather than testing or discussing the validity of the claim. Only eight studies (12 per cent) explicitly set out to test propositions derived from LI (see appendix for further details).

\footnotetext{
${ }^{6}$ One of the articles (Checkel 1999) turned out to focus on the Council of Europe and was therefore dropped from the analysis.
} 
Nevertheless, most (81 per cent) of the articles engage in some form of critique or support of liberal intergovernmentalism, and many of them raise more than one question relating to LI. In total, the 70 articles in the sample included 116 issues relating to LI, i.e. theoretical and/or empirical propositions that contain critique against, or support for, some of the main elements of LI. In coding the critique and support I have relied on the authors' own treatment of LI in relation to his or her article, rather than imposing my own evaluation of how the study at hand relates to LI, unless the reference to LI has been judged as inaccurate. ${ }^{7}$

The references that are critical to one or more aspects of LI clearly outnumber (70 per cent) those that support ( 25 per cent) the theory. ${ }^{8}$ Furthermore, articles where LI is a central component to the argument tend to be more critical than those where LI is only briefly mentioned. ${ }^{9}$ There is also a methodological divide in the distribution of critique and support. The number of articles using quantitative or qualitative methods is fairly even in the sample. ${ }^{10}$ However, studies using quantitative methods are far less likely to be critical to propositions made in LI (37 per cent of the issues raised contain critique against LI) than studies based on qualitative methods ( 82 per cent of the issues are critical). Most of the research relates to the Council of Ministers, only a few studies deal directly with the European Council.

In what follows I will briefly highlight the main thrust of the most frequently made points in favor of and against LI. Figure 1 shows the main themes that are raised in relation to LI in the sample of studies analyzed, and the share of critique and support for each of them.

[Figure 1 about here]

\footnotetext{
${ }^{7}$ Being fairly generous, I found that $78 \%$ of the articles gave a fair representation of LI, while the remaining included at least one reference that was somewhat dubious (14\%) or even outright misleading (7\%).

${ }^{8} \mathrm{Six}$ issues (5\%) were coded as ambivalent in this regard.

${ }^{9}$ In the articles where LI was coded as "central", or "fairly central", to the argument 80 per cent of the references raised critique against LI. In the articles where LI was coded "not central" 54 per cent of the issues raised where critical.

${ }^{10}$ About one third of the articles use mainly quantitative or qualitative methods respectively. The remaining articles use mixed methods, formal modelling, conceptual analysis or other approaches (including e.g. literature reviews).
} 
MS preferences: exogenous. A frequently raised theme in the literature relates to the claim made in LI that the preferences that member states pursue in the intergovernmental negotiations are determined at the domestic level, and may be treated as exogenous to, and fixed during, the negotiation processes in the Councils. The critique focuses in particular on the possible impact of the negotiation process on individual negotiators. ${ }^{11}$ Rather than constituting faithful voices of domestic political equilibria, Brussels negotiators may be vulnerable to the influence of socialization, persuasion and informal norms inherent to the negotiation 'environment', possibly deriding them from the path determined in the domestic political game (Lewis 1998, 2000, 2003, 2005, Puetter 2012, Fouilleux et al 2005, Bickerton et al 2015, Neyer 2003, Niemann 2004, Groenleer \& Van Schaik 2007, Howorth 2012). The key challenge here for LI has been cogently stated by Lewis, citing the German COREPER Ambassador Dietrich von Kyaw saying that "back home he was known as the ständiger Verräter (permanent traitor) instead of the ständiger Vertreter (permanent representative)" (Lewis 2005:938).

Although the critique is more frequent, this is also a theme that contains a fair amount of support for LI. Support comes in the form of empirical studies that refute socialization as an important factor impacting on negotiators (Beyers 2005, König 2007), and studies that demonstrate how government preferences in Council negotiations may be credibly derived from domestic conditions and constraints (Aspinwall 2007, Featherstone 2011, Givens \& Luedtke 2004).

Rational choice. Closely related to the question of preference formation is the debate between rational choice and constructivist approaches to international relations, which appears also in the Council literature. Most of the works that criticize LI for assuming exogenously formed preferences that remain fixed during the negotiations, also frame their critique in constructivist and/or social institutionalist and/or logic of appropriateness terms. ${ }^{12}$ In this debate, LI unsurprisingly receives support from rational institutionalists (Tsebelis \& Garrett 2001, Konig 2007, Golub 2007).

\footnotetext{
${ }^{11}$ See also e.g. Eising 2002:87 for a broader conception of member states" "learning".

${ }^{12}$ See references above. Beyers, whose empirical findings did not support a "strong" version of socialization in the Council working groups and committees, nevertheless join the critique against a rationalist intergovernmental "hard bargaining" image of the Council (2005:932).
} 
MS decide. Another frequent point of critique concerns which actors matter the most for the decision-making in the Councils, and for European integration generally. While LI assumes that the significant choices for Europe are made by state governments, others point at the importance of supranational, sub-national and non-state actors for explaining processes and outcomes. Critique comes from the rational institutionalists, pointing at the agenda-setting role of the Commission, and the agenda-setting and veto powers of the European parliament (Garrett \& Tsebelis 1996, Tsebelis \& Garrett 2001, Garrett 1995, Tsebelis \& Kreppel 1998), from those emphasizing the Council support functions of the Presidency (Tallberg 2004, 2010) and the General Secretariat (Beach 2004), from multi-level governance scholars pointing at the role of sub-national actors and NGOs in Brussels (Perry 2007), as well as from specific case studies on chemicals policy (Selin 2007) and electricity policy (Eising 2002) where other actors than states have been found to play important roles for the outcomes. On the other hand, some studies support the proposition that member states dominate EU decision making. One study of competition policy in the electricity sector in the 1990s found a constrained and limited role for the Commission compared to the member states, which was interpreted as support for LI (Schmidt 1998). Similar backing regarding the decisive role of the member states is also noted in a study of the developments in immigration policy in the late 1990s and early 2000s (Givens \& Luedtke's 2004).

MS preferences: sources. LI is sometimes perceived to claim that economic, or producer interests, are the only relevant types of domestic interests in the preference formation process (e.g. Scharpf 2001:5). This may not be an entirely fair interpretation of the original texts, which are open to other types of policy preferences depending on the policy problems at hand (Moravcsik 1993:491ff). Nevertheless, two alternative or complementary sources of preferences are advanced in the Council literature, as explicit points of critique against LI. These come from the rational institutionalist and postfunctionalist camps respectively.

The rational institutionalist critique, in this context, argues that the primary focus in LI on policy related preferences misses the important fact that rational and informed member states also must have preferences over the set of institutions that are put in place to implement policy. According to this view, LI assumes that pooling and delegation only serves the purpose of locking in ready-made policy bargains through credible commitments, which is too simple. The choice of institutions in treaty-amending negotiations will impact on how (and presumably which) policies are going to be implemented. The study of institutional 
consequences, which is central to the rationalist institutionalists agenda, is therefore "logically prior" to the focus on institutional choice (Tsebelis and Garrett 2001:385).

Another challenge to the preference formation component of LI comes from scholars criticizing what is perceived as an "unnecessarily reductive notion of domestic politics" (Bickerton et al 2012:717) in LI. The argument echoes the postfunctional theory of Hooghe and Marks (2009), emphasizing the increasing politicization of EU politics since the mid 1990s, the significance of ideological and identity related factors for the formation of views on European integration, and the role of parties, public opinion and elections in determining government preferences. I will return to this debate in the next section.

The initial focus in LI on major treaty-amending negotiations, as discussed in the introduction, has generated a number of different types of critique that surface in the Council literature.

Everyday decision-making. First, historical and rationalist institutionalists argue that European integration takes place also — or even mainly_in between the intergovernmental conferences. Not even the goal of constructing a parsimonious theory, according to this view, can justify ignoring the substantive impact of legislation and everyday decision-making on the integration process. The treaties are just "the tip of the iceberg" (Garrett and Tsebelis 1996:293), and only by analyzing "the policies that are produced every day in the EU" is it possible to understand "the nature of the integration process itself" (ibid:294).

Unintended consequences. Second, and closely connected, is the question of unintended consequences, and the member states' ability to control the powers that are being delegated. LI, according to Farrell and Heritier, "rests on the contestable theoretical assumption that the principals in complex principal-agent relationships can draft complete contracts which will cover all contingencies" (Farrell and Heritier 2007:227). Although this particular quote seems to be building a strawman ${ }^{13}$, the point here is that delegation contains more risks and uncertainties than acknowledged in LI.

\footnotetext{
${ }^{13}$ In Preferences and Power, Moravcsik suggests "to view delegation as a response to the problem of incomplete contracting" (Moravcsik 1993:509).
} 
Institution-free negotiations. A third issue that also relates to the focus on treaty negotiations in LI concerns the validity of the assumption of relatively decentralized institution-free intergovernmental negotiations. The critique here mainly concerns the application of LI to the Council of Ministers (Garrett \& Tsebelis 1996, Fouilleux et al 2005). It is notable that few scholars seem to doubt that the assumption is reasonable when it comes to the European Council.

MS informed and efficient negotiations. A further set of studies address the assumption in LI that the intergovernmental negotiations in the Councils are 'naturally efficient', in the sense that information is generally available to the member states and transaction costs relating to the process of reaching Pareto-optimal agreements are low. Part of the critique comes from scholars simply claiming that "deliberation" (in contrast to bargaining) is "a necessary condition" (Puetter 2012:164, see also, Neyer 2003:690) for member states to reach effective agreements. A more elaborate objection has been raised by scholars building on rational institutionalism to theorize the role of the two main support functions in the Council, the Presidency (Tallberg 2004, 2010) and the General Secretariat (Beach 2004). The claim in these studies is that, on the one hand, the member states would not be able to reach efficient agreements without the assistance of these actors (who provide agenda management and brokerage). On the other hand, relying on these support functions involve agency problems. ${ }^{14}$ Support for LI in relation to this theme comes from studies emphasizing the relative informational advantage of national administrations compared to the Commission (Franchino 2004, Gornitzka \& Sverdrup 2011).

Power (large MS and issue-specific) and credible commitments. The conceptualization of power in LI as derived primarily from asymmetric interdependence, rather than structural power resources or other forms of power, is rarely questioned in the Council literature (except for the constructivist notion of persuasion). In one of the few studies in the sample focusing specifically on the European Council, based on interviews with heads of state and government, Tallberg finds support for the proposition in LI that member states' power and influence depend on their evaluations of the alternatives to agreement. As a consequence, the larger member states do not wield equal influence across issues, and smaller states may

\footnotetext{
${ }^{14}$ In his first account of the EU Presidency, Tallberg notes that in regards to LI the role of the Presidency may be interpreted as a mechanism by which member states manage to reduce transaction costs without external intervention (Tallberg 2004:1020).
} 
sometimes 'punch above their weight' (Tallberg 2008:692). On the other hand, a somewhat questionable interpretation of LI claims that the theory holds that 'large member states are the most powerful', and subsequently raise critique when they find evidence that contrast with this proposition (Kaeding and Selck 2005:282, Selin 2007:66. For a critique of this interpretation of LI, see Franchino 2012:327). Those few studies (4) that address LI's proposition that the demand for credible commitments drives institutional choice are generally supportive.

In sum, perhaps unsurprisingly, the themes addressed in the Council literature reflect those of the broader debates over European integration, pertaining to the differences between rational choice theory, constructivism, institutionalism, multi-level governance and postfunctionalism. Most attention, and critique, in the Council literature is devoted to LI's treatment of the preference formation phase, and the interaction between member states and other actors, rather than to the intergovernmental bargaining phase. Little discussion relates to LI's central assumptions regarding sector-bound asymmetric interdependence as the main source of power and determinant of distributive outcomes. The potential challenge in this regard posed by postfunctional theory is discussed in the next section. The studies that do attend to the bargaining phase tend to focus either on modes of interaction (arguing/bargaining), or on the inherent (in)effectiveness of the negotiations, rather than on the distributive side of the negotiations. Therefore, LI's proposition regarding who gets what in these negotiations, as determined by the relative values attached to cooperation, remains largely unchallenged.

Again its notable that although LI is by far the most frequently cited theory in the Council literature, and despite the strong emphasis in Power and Preferences and The Choice for Europe on the importance of constructing a testable theory, few studies explicitly set out to test predictions generated by LI in a standard positivist manner. Instead they most often either 1) refer briefly to LI in order to emphasize the broader relevance of their own argument (usually in the introduction or the conclusion), 2) refer to a specific proposition in LI to support their own argument, or 3) criticize LI for providing only a partial account of the specific part of the EU that they study. One possible explanation for the lack of straightforward tests is the incentive for scholars to provide their own theoretical contribution in order to be able to publish their work. It could also be that LI is less straightforwardly testable than it claims to be. Overall, the way LI has been applied to the Council research contributes to confirming its status as a baseline theory of European integration. 


\section{What are the most serious challenges to LI's account of Council negotiations?}

One question that is frequently raised concerns the applicability of LI to everyday decisionmaking in the Council, including its claims regarding a relatively institution-free and naturally efficient negotiation environment. To this, I will just briefly note that the fact that the Council is formally embedded in a bicameral system of sorts, and that EU legislation is increasingly negotiated in early agreements between the Commission, the Council and the EP, impacts also on the negotiations within the Council (Hagemann and Höyland 2010, Naurin and Rassmusen 2011). ${ }^{15}$ Still, it is notable that one of the most consistent research findings is that the role of formal procedures in EU decision-making are often overestimated (Kleine 2013), and that legislative outcomes are best explained by a simple salience-weighted average of member states' preferences (Achen 2006, Thomson 2011, Franchino 2012:330).

Quantitatively, the dominating critique against LI in the Council research concerns its rational choice framework and the endogeneity of member states' preferences to the negotiations, in particular through processes of socialization and deliberation. ${ }^{16}$ Space constraints forces me to prioritize, and for the rest of this article I will focus attention on an issue that has not already been discussed at length over the years, and which I find potentially more demanding for LI. This is the postfunctionalist argument that sector-specific political-economic rationality is being complemented, or perhaps replaced, by identity and ideology as the main sources of member states' preferences. In this section, I will broaden the scope of the literature discussed to include also studies that were not part of the search result analyzed in the previous section.

\section{Postfunctional intergovernmental bargaining?}

\footnotetext{
${ }^{15}$ However, some studies have found that the effect on the Council may be less than anticipated (Häge and Naurin 2013, Mühlböck 2013)

16 The appendix includes a brief assessment of the debate about endogeneity of preferences to the negotiations (where the conclusion is that there is little evidence that socialization and deliberation in Brussels do more than complement domestic processes of preference formation).
} 
The assumptions made in LI regarding the main sources of bargaining power in Council negotiations seem to have been largely (although mostly implicitly) accepted in the Council literature. Few studies address the claim that distributive outcomes are best explained by asymmetric interdependence, based on varying sector-specific interests. Those that do tend to be in support of LI (Mayer 2008, Tallberg 2008, Naurin 2010). However, the postfunctionalist argument contains elements that, at least in theory, could have serious consequences for LI's account of what determines distributive bargaining in the Councils.

According to the postfunctionalist story, European integration has become increasingly politicized since the mid-1990s (Hooghe and Markes 2009). Nationalism, or national sovereignty as an ideological value, has been successfully (re)introduced into European politics by entrepreneurial political parties, forcing mainstream parties to direct more attention to the European integration dimension. Government representatives - who are also party representatives - cannot ignore the mobilization of salience within the electorate regarding the territorial location of political decision-making. The critique against LI from postfunctionalists has mainly concerned the sources of preferences of member states, and its account of the dynamics of domestic politics. Identification with imagined communities and ideological convictions concerning national sovereignty may be equally, if not more, important as sources of policy preferences than political-economic calculations, the argument goes. Furthermore, such preferences are being mobilized in public opinion and made consequential through party politics and elections, rather than through inside lobbying by specifically affected interest groups.

What does the politicization of European issues along a pro/anti integration dimension mean for intergovernmental bargaining in the Councils? Postfunctionalists do not theorize in much detail the consequences for intergovernmental bargaining of the empirical trends they observe. Hooghe and Marks argue that "the European Union is no longer insulated from domestic politics", and that "party leaders in positions of authority must look over their shoulders when negotiating European issues" (Hooghe and Marks 2009:5). If and how postfunctional intergovernmental bargaining would differ from functional (?) bargaining is not explicated. Moravcsik, on the other hand, argues in The Choice for Europe that if member states bargain mainly on the basis of ideological preferences on a federalist-nationalist dimension, one implication will be that variation in preferences for cooperation - and hence variation in relative power based on asymmetric interdependence-will occur only between countries, rather than between countries and issue areas (Moravcsik 1998:34). 
This is a crucial difference. If member state representatives with Eurosceptic parties and publics have started to act primarily on ideological preferences, and therefore are less willing to cooperate across the board, the logic of asymmetric interdependence would make them the most powerful actors in all negotiations that involve additional pooling and delegation of power. Their ability to reverse the course of integration, on the other hand, by scaling back powers at the European level, would be less potent as the more Eurofriendly states would attach relatively lower value to such an agreement. One condition for negotiations to be affected in this way is that the territorial issue is at stake. This is sometimes, but far from always, the case in the Council. Many policy reforms during the era of 'constraining dissensus', as the period since the ratification debacle regarding the Maasticht treaty in the early 1990s has been labelled by postfunctionalists, have concerned the direction or levels of regulations and subsidies, rather than the level of integration (Börzel 2005). In these cases, preferences are unlikely to be based on the integration dimensions, but rather on left-right ideology or-as assumed by LI-on sectoral issue-specific interests.

What is the evidence of Council negotiations being affected by the trends described in the postfunctionalist narrative? Are member states increasingly defending ideological, and in particular pro/anti EU sentiments, rather than sector-specific economic interests? Have positions become government-specific - depending on the parties in power and their relationship to an increasingly concerned electorate - rather than issue-specific and sectorbound? Are such trends affecting the relative power, and the coalitions forged, between member states?

In one of the few studies of the role of party ideology in the European Council, based on qualitative interviews and case studies of the negotiations on the employment chapter of the Amsterdam Treaty and the Lisbon agenda, Tallberg and Johansson find that national issuespecific interests dominate over party ideology: "The heads of government are seldom mobilized along transnational party lines, and decision outcomes instead tend to reflect issuespecific coalition patterns" (Tallberg and Johansson 2008:1222). In a similar vein, Schimmelfennig finds in his account of the EUs handling of the crises relating to the euro (from 2010) and migration (from 2015) — two areas that would seem to be most likely cases for finding an impact of ideology and identity factors, given the extraordinary high salience and mobilization of parties and public opinion - that the positions defended by member states are best explained by political-economic issue-specific interests. Changes to the party 
composition of governments did not matter much for the positions taken during the crises (Schimmelfennig 2017).

Cross-sectoral studies of member state behavior in the Council give a more mixed picture, although there is little evidence overall that party ideology plays a major role in the negotiations. Several studies have made use of the voting records to gain information on conflict patterns. The findings are inconclusive when it comes to the role of party ideology (Mattilla 2004, 2009, Hayes-Renshaw et al 2006, Hagemann 2008, Hagemann and Höyland 2008, Hosli et al 2011, Bailer et al 2015, Hageman et al 2017). For example, two more recent studies reach opposite conclusions. Bailer et al (2015) studied all legislative proposals in the period from May 2004 to November 2009. They found no effect of governments' party ideology (left-right or pro/anti European integration), or of having a more Eurosceptic public opinion, on the likelihood of recording an opposing vote. Hageman et al (2017), on the other hand, studied a longer time period (1999-2011), and made a deliberate selection of policy areas where the issues at stake were more likely to involve further extension of authority to the EU level. They found that member states were more likely to signal discontent in the voting records when cabinets were comprised of left-wing and/or Eurosceptic parties, and when governments faced a Eurosceptic domestic public opinion.

A problem for this line of research is that the voting records display very little variation in behavior, since member states vote in favor of the final agreement more than 98 per cent of the time. Some studies have unsurprisingly found that there is correlation between whether member states get what they want in the negotiations, and the likelihood of registering dissent (Arregui and Thomson 2014, Høyland and Wøien Hansen 2014). Nevertheless, it is hazardous to draw conclusions about the nature of intergovernmental bargaining in the Council from the voting records. The decision to register discontent is taken when the negotiations are over and the outcome is determined, and is best interpreted as a balancing act between incurring reputational costs among peers in the Council and signaling to domestic constituencies (Novak 2013, Arregui and Thomson 2014, Bailer et al 2015, Hagemann et al 2017).

Another set of studies base their analyses on large-scale interview projects, where participants in the Council negotiations are asked about their policy positions, or tendency to seek cooperation with other state representatives. The latter tend to find that member state representatives cooperate with like-minded neighboring countries, regardless of which parties that are in government (Elgström et al 2001, Naurin and Lindahl 2008, 2010). Thomson's 
work on states' policy positions shows no evidence that party preferences — whether LeftRight or Pro/Anti European integration - significantly affect the positions taken by states in the Council negotiations (Thomson et al 2004, Thomson 2009, Thomson 2011). Instead, the positions are best explained by specific national interests in the issues at hand (Thomson 2011:78). ${ }^{17}$ Furthermore, when it comes to alignments between states, Thomson finds that the most striking pattern in the data is precisely the lack of clear patterns (2011:76). Alignments change frequently, depending on the issues at hand, just as LI would expect.

In sum, there are few signs that the trend towards party politicization and increased attention to EU politics in public opinion since the Maastricht Treaty have altered the nature of negotiations in the Councils. There may be several reasons why that is the case. The relative weight of territorial affinity, or nationalism, compared to economic and public regulatory interests may be lighter than argued by postfunctionalists. The fact that hardline Eurosceptic parties so far have mostly been kept out of government power has also likely moderated the salience of the integration dimension in the Councils. ${ }^{18}$ Furthermore, the low level of transparency in the Councils continues to sheltering the negotiations from mass publics (but not necessarily from special interests). Although the Council of Ministers has increased its "transparency in process" in the last decades, releasing a massive number of documents relating to the negotiations, it still lacks "transparency in rationale" (Naurin 2017). In contrast to the European Parliament and domestic legislatures, the Council does not have an arena for public debate, where justifications for policy choices may be stated and contrasted to the alternatives, and where connections to broader ideological goals can be made. It has the closed-door committees of ordinary legislatures, where functional sector-based negotiations take place, but not the plenary where wider principles are raised. Thus, in spite of the increased heat around European issues in domestic politics, the Council still provides a decision-making environment well-suited for the type of functional political-economic bargaining mechanisms that are central to LI.

\footnotetext{
${ }^{17}$ In an interesting analysis of the same data (the DEU-project) Wratil finds that member states positions were systematically correlated with public opinion on issues that were (predefined as) relating to the left-right dimension, but only sporadically so to issues relating to the pro-anti EU dimension (Wratil 2017).

18 "So far" and "mostly" should be emphasized here. Recent exceptions include Poland, Hungary and Italy.
} 


\section{Conclusions}

Although most research on the Councils of the EU do not refer to liberal intergovernmentalism, in relative terms LI overshadows all other theories of European integration and policy-making in the EU in this literature. Most of the references made raise critique against LI, often including claims about how the theory may be complemented to provide a more comprehensive account of the interstate bargaining that takes place in these institutions. Few studies claim that LI fundamentally misjudges the main driving forces behind the formation and aggregation of preference in the Councils. Furthermore, the most significant challenges raised seem manageable from the perspective of LI, when looking at the relevant empirical research. On the other hand, much of the engagement with LI is fairly superficial, and few studies provide systematic tests of the key assumptions of LI with regard to interstate bargaining, despite the theory's explicit emphasis on the importance of specifying testable implications. As a result, the status of LI as a baseline theory is confirmed in the Council literature more by implicit (and perhaps somewhat grudging) consent than overt support.

\section{References}

Achen, C.H. (2006) 'Evaluating political decision-making models'. In Thomson, R., Stokman, F.N., Achen, C.H. and König, T. (eds.) The European Union Decides(Cambridge: Cambrideg University Press).

Arregui, J. and Thomson, R. (2014) 'Domestic adjustment costs, interdependence and dissent in the Council of the European Union'. European Journal of Political Research, Vol. 53, No. 4, p.pp. 692-708.

Aspinwall, M. (2007) 'Government preferences on European integration: An empirical test of five theories'. British Journal of Political Science, Vol. 37, p.pp. 89-114.

Bailer, S., Mattila, M. and Schneider, G. (2015) 'Money Makes the EU Go Round: The Objective Foundations of Conflict in the Council of Ministers'. Jcms-Journal of Common Market Studies, Vol. 53, No. 3, p.pp. 437-56.

Beach, D. (2004) 'The unseen hand in treaty reform negotiations: the role and influence of the Council Secretariat'. Journal of European Public Policy, Vol. 11, No. 3, p.pp. 408-39. 
Beyers, J. (2005) 'Multiple embeddedness and socialization in Europe: The case of council officials'. International Organization, Vol. 59, No. 4, p.pp. 899-936.

Beyers, J. (2010) 'Conceptual and Methodological Challenges in the Study of European Socialization'. Journal of European Public Policy, Vol. 17, No. 6, p.pp. 909-20.

Bickerton, C.J., Hodson, D. and Puetter, U. (2015) 'The New Intergovernmentalism: European Integration in the Post-Maastricht Era'. Jcms-Journal of Common Market Studies, Vol. 53, No. 4, p.pp. 703-22.

Borzel, T.A. (2005) 'Mind the gap! European integration between level and scope'. Journal of European Public Policy, Vol. 12, No. 2, p.pp. 217-36.

Checkel, J.T. (2005) 'International institutions and socialization in Europe: Introduction and framework'. International Organization, Vol. 59, No. 4, p.pp. 801-26.

Eising, R. (2002) 'Policy learning in embedded negotiations: Explaining EU electricity liberalization'. International Organization, Vol. 56, No. 1, p.pp. 85-+.

Elgstrom, O., Bjurulf, B., Johansson, J. and Sannerstedt, A. (2001) 'Coalitions in European Union negotiations'. Scandinavian Political Studies, Vol. 24, No. 2, p.pp. 111-28.

Farrell, H. and Heritier, A. (2007) 'Introduction: Contested competences in the European Union'. West European Politics, Vol. 30, No. 2, p.pp. 227-43.

Featherstone, K. (2011) 'The Greek Sovereign Debt Crisis and EMU: A Failing State in a Skewed Regime'. Jcms-Journal of Common Market Studies, Vol. 49, No. 2, p.pp. 193-217.

Fouilleux, E., de Maillard, J. and Smith, A. (2005) 'Technical or political? The working groups of the EU Council of Ministers'. Journal of European Public Policy, Vol. 12, No. 4, p.pp. 609-23.

Franchino, F. (2004) 'Delegating powers in the European Community'. British Journal of Political Science, Vol. 34, p.pp. 269-93.

Franchino, F. (2012) 'Challenges to Liberal Intergovernmentalism'. European Union Politics, Vol. 14, No. 2, p.pp. 324-37.

Garrett, G. (1995) 'FROM THE LUXEMBOURG COMPROMISE TO CODECISION DECISION-MAKING IN THE EUROPEAN-UNION'. Electoral Studies, Vol. 14, No. 3, p.pp. 289-308.

Garrett, G. and Tsebelis, G. (1996) 'An institutional critique of intergovernmentalism'. International Organization, Vol. 50, No. 2, p.pp. 269-\&.

Givens, T. and Luedtke, A. (2004) 'The politics of European Union immigration policy: Institutions, salience, and harmonization'. Policy Studies Journal, Vol. 32, No. 1, p.pp. 145-65. 
Golub, J. (2007) 'Survival analysis and European Union decision-making'. European Union Politics, Vol. 8, No. 2, p.pp. 155-79.

Gornitzka, A. and Sverdrup, U. (2011) 'Access of Experts: Information and EU Decisionmaking'. West European Politics, Vol. 34, No. 1, p.pp. 48-70.

Groenleer, M.L.P. and Van Schaik, L.G. (2007) 'United we stand? The European union's international actorness in the cases of the international criminal court and the Kyoto protocol'. Jcms-Journal of Common Market Studies, Vol. 45, No. 5, p.pp. 969-98.

Hage, F.M. and Naurin, D. (2013) 'The effect of codecision on Council decision-making: informalization, politicization and power'. Journal of European Public Policy, Vol. 20, No. 7, p.pp. 953-71.

Hagemann, S. (2008) 'Voting, Statements and Coalition-Building in the Council. Party Politics and National Interests'. In Naurin, D. and Wallace, H. (eds.) Unveiling the Council of the EU. Games Governments Play in Brussels. (Basingstoke: Palgrave Macmillan).

Hagemann, S., Hobolt, S.B. and Wratil, C. (2017) 'Government Responsiveness in the European Union: Evidence From Council Voting'. Comparative Political Studies, Vol. 50, No. 6, p.pp. 850-76.

Hagemann, S. and Hoyland, B. (2008) 'Parties in the Council?'. Journal of European Public Policy, Vol. 15, No. 8, p.pp. 1205-21.

Hayes-Renshaw, F., Van Aken, W. and Wallace, H. (2006) 'When and why the EU Council of Ministers votes explicitly'. Jcms-Journal of Common Market Studies, Vol. 44, No. 1, p.pp. 161-94.

Hayes-Renshaw, F. and Wallace, H. (2006) The Council of Ministers (Basingstoke: Macmillan).

Hix, S. (1999) 'Dimensions and alignments in European Union politics: Cognitive constraints and partisan responses'. European Journal of Political Research, Vol. 35, No. 1, p.pp. 69-106.

Hooghe, L. and Marks, G. (2009) 'A Postfunctionalist Theory of European Integration: From Permissive Consensus to Constraining Dissensus'. British Journal of Political Science, Vol. 39, p.pp. 1-23.

Hosli, M.O., Mattila, M. and Uriot, M. (2011) 'Voting in the Council of the European Union after the 2004 Enlargement: A Comparison of Old and New Member States'. JcmsJournal of Common Market Studies, Vol. 49, No. 6, p.pp. 1249-70.

Hoyland, B. and Hansen, V.W. (2014) 'Issue- specific policy- positions and voting in the Council*'. European Union Politics, Vol. 15, No. 1, p.pp. 59-81.

Jacobsson, K. and Åsa, V. (2007) 'Deliberative Transnationalism? Analysing the role of committee interaction in soft co-ordination'. In Linsenmann, I., Meyer, C.O. and Wessels, W.T. (eds.) Economic government of the EU : a balance sheet of new modes of policy coordination (Basingstoke: Palgrave Macmillan). 
Joerges, C. and Neyer, J. (1997) 'Transforming strategic interaction into deliberative problem-solving: European comitology in the foodstuffs sector'. Journal of European Public Policy, Vol. 4, No. 4, p.pp. 609-25.

Kaeding, M. and Selck, T.J. (2005) 'Mapping out political Europe: Coalition patterns in EU decision-making'. International Political Science Review, Vol. 26, No. 3, p.pp. 27190 .

Kleine, M. (2013) Informal Governance in the European Union. How Governments Make International Organizations Work (Ithaca: Cornell University Press).

Konig, T. (2007) 'Divergence or convergence? From ever-growing to ever-slowing European legislative decision making'. European Journal of Political Research, Vol. 46, No. 3, p.pp. 417-44.

Lewis, J. (1998) 'Is the 'hard bargaining' image of the Council misleading? The Committee of Permanent Representatives and the local elections directive'. Journal of Common Market Studies, Vol. 36, No. 4, p.pp. 479-504.

Lewis, J. (2000) 'The methods of community in EU decision-making and administrative rivalry in the Council's infrastructure'. Journal of European Public Policy, Vol. 7, No. 2, p.pp. 261-89.

Lewis, J. (2003) 'Institutional environments and everyday EU decision making - Rationalist or constructivist?'. Comparative Political Studies, Vol. 36, No. 1-2, p.pp. 97-124.

Lewis, J. (2005) 'The janus face of Brussels: Socialization and everyday decision making in the European Union'. International Organization, Vol. 59, No. 4, p.pp. 937-71.

Marks, G., Hooghe, L. and Blank, K. (1996) 'European integration from the 1980s: Statecentric v multi-level governance'. Journal of Common Market Studies, Vol. 34, No. 3, p.pp. 341-78.

Mattila, M. (2004) 'Contested decisions: Empirical analysis of voting in the European Union Council of Ministers'. European Journal of Political Research, Vol. 43, No. 1, p.pp. 29-50.

Mattila, M. (2009) 'Roll call analysis of voting in the European Union Council of Ministers after the 2004 enlargement'. European Journal of Political Research, Vol. 48, No. 6, p.pp. 840-57.

Moravcsik, A. (1993) 'PREFERENCES AND POWER IN THE EUROPEANCOMMUNITY - A LIBERAL INTERGOVERNMENTALIST APPROACH'. Journal of Common Market Studies, Vol. 31, No. 4, p.pp. 473-524.

Moravcsik, A. (1998) The Choice for Europe: Social purpose and state power from Messina to MaastrichtCornell University Press).

Moravcsik, A. and Schimmelfennig, F. (2009) 'Liberal Intergovernmentalism'. In Wiener, A. and Diez, T. (eds.) European Integration Theory (Oxford: Oxford University Press). 
Mühlböck, M. (2013). "Linking Council and European Parliament? Voting unity of national parties in bicameral EU decisionmaking." Journal of European Public Policy 20(4): 571-588.

Naurin, D. (2010) 'Most Common When Least Important: Deliberation in the European Union Council of Ministers'. British Journal of Political Science, Vol. 40, p.pp. 3150 .

Naurin, D. (2017) 'The Puzzle of Transparency Reforms in the Council of the EU'. Politics and Governance, Vol. 5, No. 3, p.pp. 87-90.

Naurin, D. and Lindahl, R. (2008) 'East-North-South. Coalition-Building in the Council Before and After Enlargement'. In Naurin, D. and Wallace, H. (eds.) Unveiling the Council of the EU: Games Governments Play in Brussels (Basingstoke: Palgrave).

Naurin, D. and Lindahl, R. (2010) 'Out in the cold? Flexible Integration and the Political Status of Euro Opt-outs'. European Union Politics, Vol. 11, No. 4, p.pp. 485-509.

Naurin, D. and Rasmussen, A. (2011) 'New External Rules, New Internal Games: How the EU Institutions Respond when Inter-institutional Rules Change'. West European Politics, Vol. 34, No. 1, p.pp. 1-17.

Neyer, J. (2003) 'Discourse and order in the EU: A deliberative approach to multi-level governance'. Journal of Common Market Studies, Vol. 41, No. 4, p.pp. 687-706.

Niemann, A. (2004) 'Between communicative action and strategic action: the Article 113 Committee and the negotiations on the WTO Basic Telecommunications Services Agreement'. Journal of European Public Policy, Vol. 11, No. 3, p.pp. 379-407.

Novak, S. (2013) 'The Silence of Ministers: Consensus and Blame Avoidance in the Council of the European Union'. Jcms-Journal of Common Market Studies, Vol. 51, No. 6, p.pp. 1091-107.

Odell, J.S. (2013) 'Negotiation and Bargaining'. In Carlsnaes, W., Risse, T. and Simmons, B.A. (eds.) Handbook of International Relations (London: Sage).

Panke, D. (2006) 'More Arguing Than Bargaining? The Institutional Designs of the European Convention and Intergovernmental Conferences Compared'. Journal of European Integration, Vol. 28, No. 4, p.pp. 357 - 79.

Perry, B. (2007) 'The multi-level governance of science policy in England'. Regional Studies, Vol. 41, No. 8, p.pp. 1051-67.

Pierson, P. (1996) 'The path to the European integration - A historical institutionalist analysis'. Comparative Political Studies, Vol. 29, No. 2, p.pp. 123-63.

Pollack, M.A. (2003) 'Control mechanism or deliberative democracy? Two images of comitology'. Comparative Political Studies, Vol. 36, No. 1-2, p.pp. 125-55.

Pollack, M.A. and Shaffer, G. (2008) 'Risk Regulation, Genetically Modified Foods, and the Failure of Deliberation in the Council of Ministers'. In Naurin, D. and Wallace, H. 
(eds.) Unveiling the Council of the EU: Games Governments Play in

Brussels (Basingstoke: Palgrave Macmillan).

Puetter, U. (2012) 'Europe's deliberative intergovernmentalism: the role of the Council and European Council in EU economic governance'. Journal of European Public Policy, Vol. 19, No. 2, p.pp. 161-78.

Scharpf, F.W. (2001) 'Notes toward a theory of multilevel governing in Europe'. Scandinavian Political Studies, Vol. 24, No. 1, p.pp. 1-26.

Schimmelfennig, F. (2001) 'The community trap: Liberal norms, rhetorical action, and the eastern enlargement of the European Union'. International Organization, Vol. 55, No. 1, p.pp. 47-80.

Schmidt, S.K. (1998) 'Commission activism: subsuming telecommunications and electricity under European competition law'. Journal of European Public Policy, Vol. 5, No. 1, p.pp. 169-84.

Selin, H. (2007) 'Coalition politics and chemicals management in a regulatory ambitious Europe'. Global Environmental Politics, Vol. 7, No. 3, p.pp. 63-+.

Tallberg, J. (2004) 'The power of the Presidency: Brokerage, efficiency and distribution in EU negotiations'. Journal of Common Market Studies, Vol. 42, No. 5, p.pp. 9991022.

Tallberg, J. (2010) 'The Power of the Chair: Formal Leadership in International Cooperation'. International Studies Quarterly, Vol. 54, No. 1, p.pp. 241-65.

Tallberg, J. and Johansson, K.M. (2008) 'Party politics in the European Council'. Journal of European Public Policy, Vol. 15, No. 8, p.pp. 1222-42.

Thomson, R. (2009) 'Actor alignments in the European Union before and after enlargement'. European Journal of Political Research, Vol. 48, No. 6, p.pp. 756-81.

Thomson, R. (2011) Resolving Controversy in the European Union (Cambridge: Cambridge University Press).

Thomson, R., Boerefijn, J. and Stokman, F. (2004) 'Actor alignments in European Union decision making'. European Journal of Political Research, Vol. 43, No. 2, p.pp. 23761.

Tsebelis, G. and Garrett, G. (2001) 'The institutional foundations of intergovernmentalism and supranationalism in the European Union'. International Organization, Vol. 55, No. 2, p.pp. 357-.

Tsebelis, G. and Kreppel, A. (1998) 'The history of conditional agenda-setting in European institutions'. European Journal of Political Research, Vol. 33, No. 1, p.pp. 41-71.

Ulbert, C. and Risse, T. (2005) 'Deliberately changing the discourse: What does make arguing effective?'. Acta Politica, Vol. 40, No. 3, p.pp. 351-67. 
Walton, R.E. and McKersie, R.B. (1965) A behavioral theory of labor negotiations; an analysis of a social interaction system (New York,: McGraw-Hill).

Warntjen, A. (2010) 'Between bargaining and deliberation: Decision-making in the Council of the European Union'. Journal of European Public Policy, Vol. 17, No. 5, p.pp. 665-79.

Wratil, C. (2018). "Modes of Government Responsiveness in the European Union: Evidence from the Council Negotiation Positions." European Union Politics 19, No.1, p.pp 5274. 
Figure 1. Distribution of critique and support for LI across different themes.

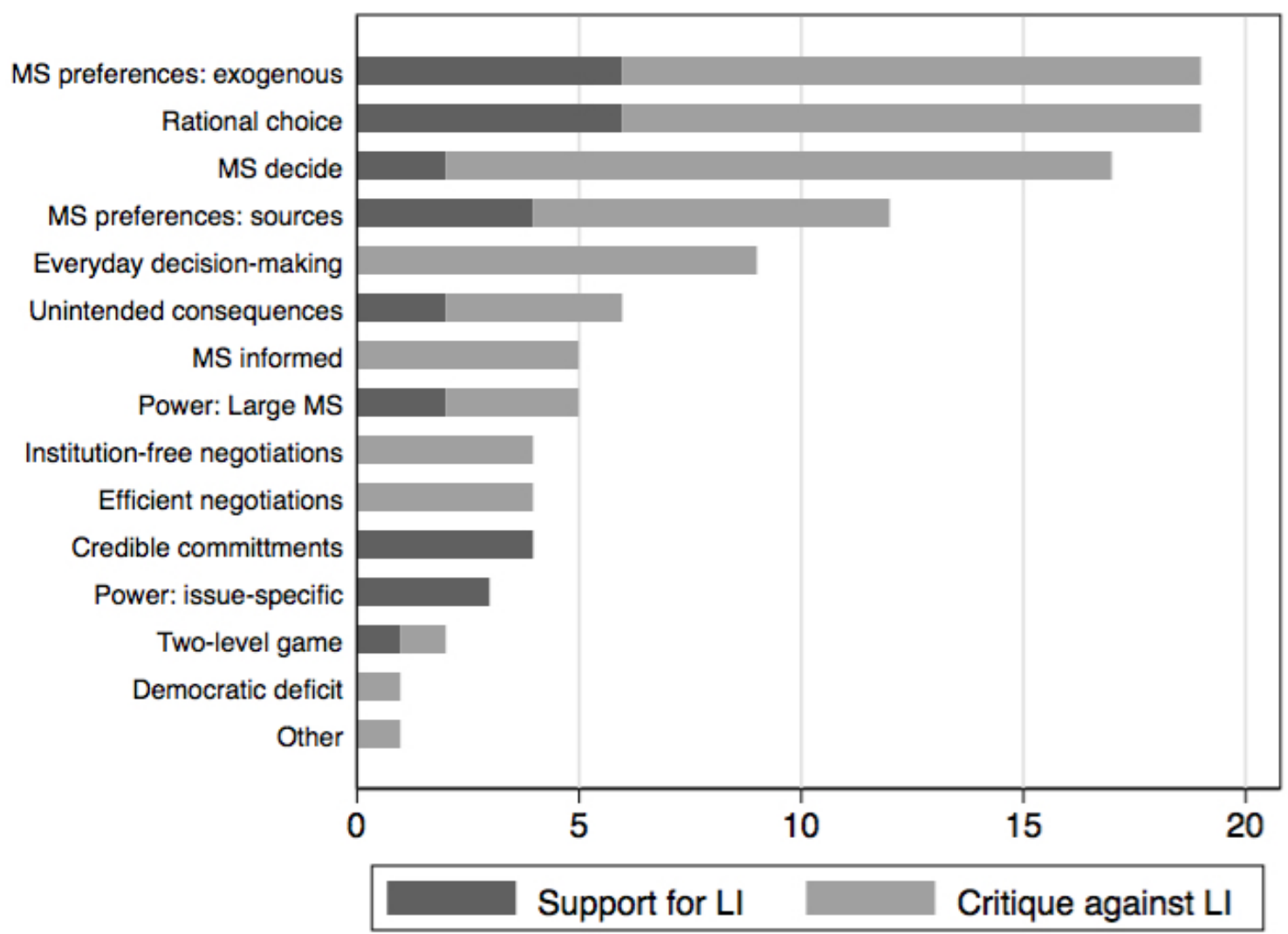

Note: The numbers refer to the 116 issues raised in the 70 articles in the sample. 